\title{
IMPACT OF R\&D INVESTMENT ON ECONOMIC GROWTH OF THE CZECH REPUBLIC - A RECURSIVELY DYNAMIC CGE APPROACH
}

\author{
Zuzana Kř́stková*
}

\begin{abstract}
:
The paper investigates how results obtained with standard CGE models can be improved by incorporating the effects of R\&D activity in a recursively-dynamic CGE model built for the economy of the Czech Republic. The main objective of the paper is to quantify the impact of R\&D activity on the long-term economic growth of the Czech Republic within the recursively dynamic CGE framework. The effect of R\&D investment is modelled via the accumulation of knowledge that is treated as a specific production factor.

The main findings show that knowledge accumulation can contribute to higher economic growth, but the impact of the dynamisation in the CGE model is very low. However, in terms of structural changes in the economy, the omission of knowledge capitalization might underestimate the tertiary sector in the longer run. The paper also investigates the efficiency of R\&D investment and concludes that in the longer run, investment in capital goods is more efficient in achieving higher economic growth. In the concluding chapter, related factors that may improve the impact of knowledge in the CGE model are discussed.
\end{abstract}

Keywords: R\&D investment, CGE model, Czech Republic, knowledge accumulation, economic growth, structural change.

JEL Classification: C68, D 58, O3, E22.

\section{Introduction}

Developed economies are facing a problem of declining competitiveness on a global scale. The perspectives for sustaining world economic leadership are associated with stimulating technological progress through innovation and investment in R\&D. Within the EU, the debates are often centred on the effective allocation of subsidies from the EU budget, in which certain support of policies, such as the common agricultural policy, occupy a considerable part. However, the idea of reallocating agricultural subsidies to the prospective sectors of the economy, such as research and development should be supported with thorough research, revealing possible impacts on the whole economy.

* Zuzana Kř́stková, CZU - Faculty of Economics and Management, Kamýcká 129, CZ-165 00 Prague 6 (kristkova@pef.czu.cz). The results of this paper are part of a Research Grant of the Czech Science Foundation P402/11/P678: "Evaluation of Research and Development Effects on the Economic Growth of the Czech Republic with the Use of a Computable General Equilibrium Model”. 
Computable General Equilibrium (CGE) models provide appropriate instruments in assessing the ex-ante impact of different policy scenarios. However, in the field of research and development, standard CGE models do not capture properly the R\&D effects, due to several factors. Firstly, national accounts usually do not explicitly include R\&D investment; secondly, the sector of R\&D included in the input-output tables does not capture all investment into research and development. Thirdly, and most importantly, the R\&D activities are not capitalized properly in the CGE model to stimulate economic growth.

This paper investigates how results obtained with standard CGE models can be improved by incorporating the effects of $\mathrm{R} \& \mathrm{D}$ activity in a recursively dynamic CGE model built for the economy of the Czech Republic. The main objective of the paper is to quantify the impact of the R\&D activities on the long-term economic growth of the Czech Republic within the recursively dynamic CGE framework.

\section{Review of Theoretical Approaches for Modelling R\&D Investments}

The progress made in understanding the endogeneity of economic growth at the beginning of the 1990s raised awareness to incorporate endogenous growth theories into CGE models. According to Zürn et al. (2007), Computable General Equilibrium models are suitable to fulfil the requirements on the instrument of the analysis regarding the sectoral, regional and chronological dimension. This can be very useful considering that innovations are not restricted to certain industries or certain areas of the economy but they include the economy as a whole.

One of the earliest contributions on implementing endogenous growth theory formalized by Romer can be found in the work of Diao, Roe and Yeldan (1999) who incorporate imperfect competition and forward looking dynamization. As Gillingham, Newell and Pizer (2008) point out, "unfortunately, theoretical models with continuous intermediate goods and abstract representations of blueprints are not well-suited to match up to measurable real-world variables or technologies that most numerical models attempt to represent". Therefore, various recent practical applications of the R\&D based theory of economic growth have been performed in the recursively dynamic CGE framework. For instance, Garau and Lecca (2009) estimate the impact of R\&D subsidies on the region of Sardinia in a regional CGE model with a recursive dynamization and perfect competition setting. Yungchang et al. (2010) have applied an R\&D-driven recursively dynamic CGE model to assess whether the private or public sector should finance research and development.

Endogenous growth theory based on R\&D has seen increasing applications in the field of climate change modelling and environmental policy (for instance Wang, Wang and Chen, 2009). To add to the review of recent works, research on R\&D investment and knowledge input has also been carried out at the Institute of Energy Economics and Rational Use of Energy, Germany. Zürn et al. (2007) applies the global CGE 
model NEWAGE-W $\mathrm{W}^{1}$ to estimate the economic and environmental impacts of R\&D investment. Zürn shows that whereas the direct input subsidy of knowledge provides benefits only from knowledge reallocation, subsidizing investment in R\&D is more efficient as it decreases relative price of this activity as opposed to the alternatives of consumption and physical investment activity and it leads to faster accumulation of knowledge.

CGE models have also gained popularity among policymakers in the Czech Republic, particularly in the field of natural resources and the environment. In conjunction with prepared environmental tax reform, the Czech ministry of the environment has applied a dynamic CGE model for the quantification of environmental policy impact on macroeconomic aggregates (Pavel, 2008). The macroeconomic effects of the environmental taxation are further analysed in Ščasný, Píša, Pollot et al. (2009) who apply structural macroeconometric E3M3 European model adjusted to the Czech economy. Another CGE model applied in relation to natural resources is the model developed at the Czech National Bank in cooperation with the Netherlands Bureau of Policy Analysis (Dybczak and van der Windt, 2008) which has been used to predict the effects of oil price shocks on the Czech economy. Concerning fiscal policy, Hurník (2004) applies a non-stochastic dynamic general equilibrium model to assess the impact of alternative fiscal consolidation programs on the Czech economy.

Despite various uses and model alternatives as described above, the issue of R\&D investment and knowledge formation as related to the endogenous growth theory has not been sufficiently analysed in the Czech Republic, at least not within the CGE framework. It should be noted, however, that there is an extensive body of research modelling the endogenous growth and knowledge accumulation using other approaches, see for instance Kejak, Seiter and Vávra (2004) or Kejak and Vávra (2002), who develop a two-sector endogenous growth model to assess the transitional behaviour after the EU accession in the CEEC countries including the Czech Republic. Furthermore, Sixta, Vltavská and Zbranek (2011) have recently presented a new approach in deriving total factor productivity with use of labour and capital services, which also includes the R\&D effects.

By explicit incorporation of knowledge as a production factor and R\&D investment in gross capital formation, this paper aims at contributing to the existing CGE model studies conducted in the Czech Republic and to improve the understanding of the role of research and development activities in the Czech economy. The description of the CGE model applied in this research, the required data source for the SAM construction and the main model modifications that incorporate investment in $R \& D$, are described in the following chapter.

$1 \quad$ National European Worldwide Applied General Equilibrium Modelling System 


\section{Description of the Methodological Approach Applied in the Paper}

\subsection{Construction of the Social Accounting Matrix with capitalized R\&D investment}

The Social Accounting Matrix (SAM) was constructed from the Czech national accounts. The base year for the calibration of the model was determined by the availability of the supply-use tables, which were used for building the production and commodity accounts of the SAM. At the time of the SAM construction, the most updated edition of the supplyuse tables was available for the year 2008. The SAM contains 18 production sectors and 19 commodities. The choice of the production structure was determined by the structure of $R \& D$ expenditure available per sector in the R\&D statistics.

The general version of the SAM was further extended to incorporate knowledge accounting. Basically, there are two sources of data that can be used for this R\&D capitalization - the System of National Accounts (SNA) and the Frascati Manual (FM) surveys following the OECD methodology. Concerning the SNA, R\&D is predominantly understood as "activity carried out with the aim to increase efficiency, productivity and future benefits" and is recorded within the supply-use tables under the NACE 72 production sector; which excludes complementary R\&D activities carried out across the remaining production sectors. On the other hand, OECD's Frascati Manual $^{2}$ considers $R \& D$ as " a creative work undertaken on a systematic basis in order to increase the stock of knowledge including knowledge of man, culture society and the use of this stock of knowledge to devise new applications". Surveys based on the Frascati Manual thus comprehensively capture all research activities in the domestic economy; however, they are not fully consistent with the National Accounts.

It should be emphasized that there has been a continuous progress of the statistical offices to properly capture the effects of research and development in National Accounts. Following the SNA 2008 revision, the expenditures on R\&D will no longer be considered as a part of intermediate consumption (in case of private research) or governmental consumption (in case of public research), but as a component of the gross fixed capital formation. This process is commonly known as capitalization of research and development in the SNA and requires harmonizing the two data sources by the use of "bridge" tables which translate Frascati Manual data (FM) to National Accounts (SNA). In this research, bridge tables constructed for the Czech Republic were adopted from Ptáčková, (2007)3. The newest contribution Equation (1) shows

2 Frascati Manual contains proposed standard practice for surveys on research and experimental development as initially agreed during OECD national R\&D experts meeting in Frascati, Italy, 1963. The newest - Sixth Edition - was released in 2002.

3 This was the most recent contribution available at the time of SAM construction. However, the latest estimates of the $\mathrm{R} \& \mathrm{D}$ capitalization in the Czech economy were performed by Zbranek and Fischer (2011). Regarding other countries see for instance M. de Haan, and M. van Rooijen-Horsten (2004) for Netherlands; Salem and Siddiqi (2006) for Canada; Galindo-Rueda (2007) for UK; Robbins (2005) for Australia and Daniels (2007) for Sweden. 
the derivation of total R\&D gross production following Ptáčková and provides the respective data sources for each component. As for the operating surplus, it is assumed that all R\&D activities have a uniform profitability rate approximated by the sector NACE 72.

$R \& D$ Gross production $=$ Labour costs $(F M)+$ Other current expenditures $(F M)$

+ Intermediate consumption of $R \& D$ commodity by $R \& D$ sector (SNA NACE 72)

+ Consumption of Gross Fixed Capital (estimate) + Operating Surplus (estimate)

+ Net taxes on production (estimate) $-R \& D$ expenditures on Software (FM).

The values of the R\&D expenditures obtained from the Frascati Manual and the translation to the SNA is displayed in Table 1. Table 1 shows that harmonizing the Frascati Manual data with SNA increases R\&D estimates by about $20 \%$. An even stronger discrepancy is found when comparing the R\&D data obtained from Frascati with the R\&D values reported in the current version of SNA. As reported in Figure 1, the gross production of the R\&D sector reached CZK 18 billion in 2008, however, the surveys from Frascati Manual reported expenditure amounting to CZK 53 billion. After harmonizing with SNA standards, the final value of gross R\&D production reaches CZK 65 billion, more than 3.5 times higher than the original values in the supply-use tables. These results confirm that in the current version of National Accounts, the size of the R\&D sector is significantly underestimated. Therefore, the SAM derived from the current SNA should be properly modified in order to avoid this bias.

Table 1

Estimation of Private R\&D Gross Production (CZK m) for 2008

\begin{tabular}{|l|r|r|r|r|}
\hline & \multicolumn{2}{|c|}{$\begin{array}{c}\text { Private Research and } \\
\text { Development }\end{array}$} & \multicolumn{2}{|c|}{$\begin{array}{c}\text { Public Research and } \\
\text { Development }\end{array}$} \\
\hline $\begin{array}{l}\text { Domestic production of R\&D } \\
\text { commodity }\end{array}$ & $\begin{array}{c}\text { Frascati } \\
\text { Manual }\end{array}$ & $\begin{array}{c}\text { SNA Modifi- } \\
\text { cation }\end{array}$ & $\begin{array}{c}\text { Frascati } \\
\text { Manual }\end{array}$ & $\begin{array}{c}\text { SNA Modifi- } \\
\text { cation }\end{array}$ \\
\hline Current Expenditure & 30,073 & 30,621 & 17,875 & 18,210 \\
\hline Labour expenditure & 12,680 & 12,680 & 9,096 & 9,096 \\
\hline Other expenditure & 17,393 & 17,941 & 8,779 & 9,113 \\
\hline Capital expenditure & 3,413 & & 2,539 & \\
\hline Land, buildings and construction & 490 & & 973 & \\
\hline Machinery, equipment, incl. software & 2,923 & & 1,566 & \\
\hline Gross capital consumption & & 12,636 & & 7,511 \\
\hline Operating surplus & & 2,493 & & \\
\hline Taxes and subsidies on production & & $-3,581$ & & \\
\hline Software development & & 2,681 & & \\
\hline Gross domestic production & $\mathbf{3 3 , 4 8 6}$ & $\mathbf{3 9 , 4 8 7}$ & $\mathbf{2 0 , 4 1 5}$ & $\mathbf{2 5 , 7 2 1}$ \\
\hline
\end{tabular}

Source: Author's calculations based on Ptáčková (2007) 
Figure 1

Comparison of Total R\&D Gross Production Reported in SNA and Frascati Manual in 2008 (CZK m)

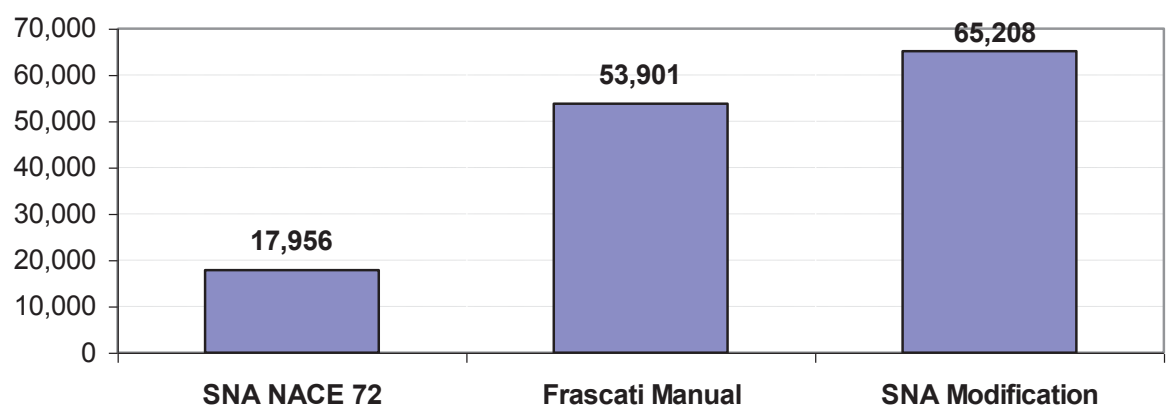

Source: Author's calculations

After the incorporation of R\&D investments into the Gross Capital Formation Account, the gross production in each sector was increased proportionally. This increase was translated partially to value added in the form of knowledge and partially to the consumption of gross fixed capital. Consequently, knowledge income was redistributed to households, firms and government in the proportion of total capital income and further fully transmitted to the savings account. The impact of the capitalization on the SAM is recorded in Figure 2, which displays a percentage change of gross value added after the capitalization per sector. The strongest increase of value added is noticed in the R\&D sector $(+31 \%)$, which participates significantly in total R\&D expenditure. However, value added is also elevated in other sectors of the economy, mainly in the car industry $(+16 \%)$, education $(+8 \%)$, ICT, chemical and pharmaceutical sector $(+6 \%)$. The effect on total gross value added is $1.7 \%$ which highlights the impact of R\&D capitalization on GDP 4 .

The final SAM after capitalization is a matrix of 54x54 size. Compared to the original version, it is extended to include: (i) account of gross R\&D investment, (ii) account of knowledge as a new production factor in the value added per each production sector and (iii) account of knowledge depreciation per each production sector.

4 This estimate is comparable to the result of Zbranek and Fischer (2011) who derive a $+1.54 \%$ effect of capitalization of R\&D on GDP in 2007. 
Figure 2

Impact of R\&D Capitalization in the Modified SAM on Gross Value Added per Sector (\% change against the original SAM)

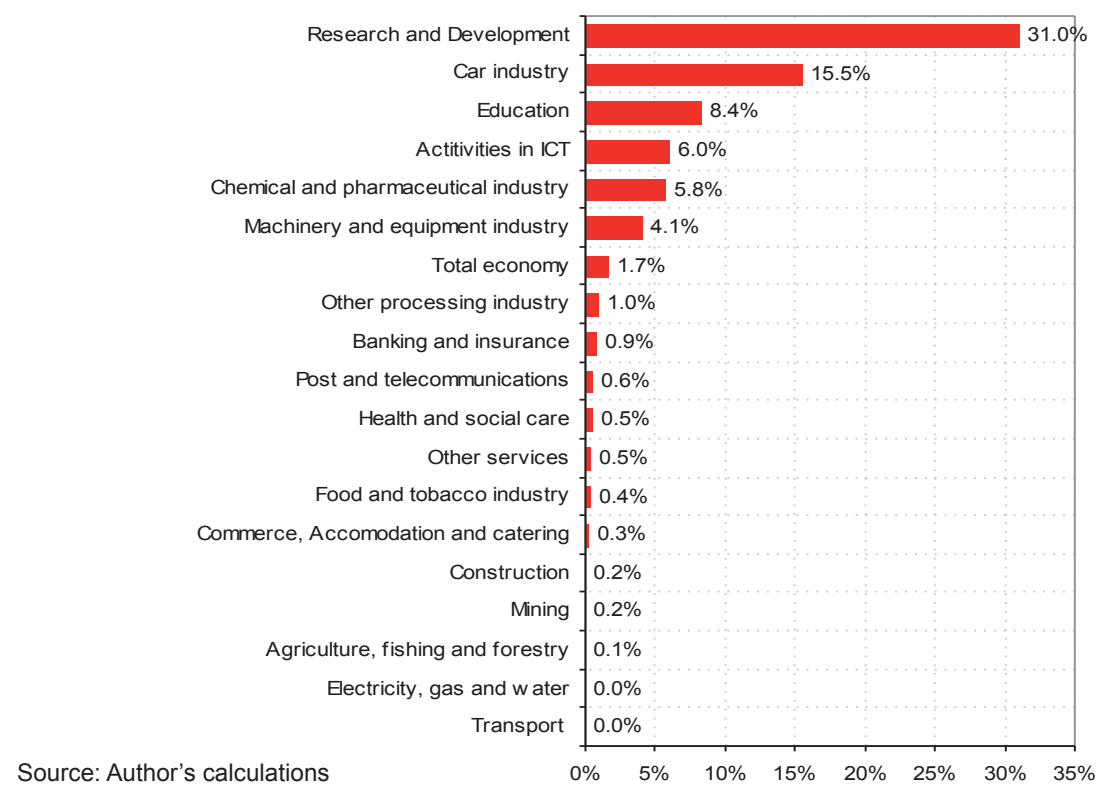

\subsection{Description of the CGE model with knowledge and R\&D investments}

In this research, the national CGE model of the Czech economy built by the author is applied. The production side of the economy is modelled following a standard CGE model structure (see Lofgren, 2002) and is described in detail in Kř́stková (2010a). The model assumes that the total gross production is a fixed factor Leontief combination of intermediate consumption and value added under perfect competition and constant returns to scale, which can be expressed by a nested production structure. The consumption behaviour of households is modelled using a Stone-Geary utility function, leading to the Linear Expenditure System.

The CGE model considers six closure and market factor assumptions: i) total supply of labour and land is fixed; capital stock grows at the rate of net investments; ii) labour unemployed is allowed and determined by the Phillips curve; iii) the model follows a standard macroeconomic balance of savings and investment; iv) the closure of the governmental account is arranged by fixing a ratio of governmental consumption to GDP; v) export and import prices are fixed; vi) both foreign sector closures (for the EU and the RoW) assume fixed foreign savings and endogenously adjusting exchange rates.

Several modifications were made to the original structure of the model in order to incorporate the effects of research and development. First of all, as knowledge is regarded as a new production factor, it must be incorporated into the production structure of the CGE model. Different alternatives can be considered, which are mainly 
related to the role of knowledge in technological progress. The original work of Romer (1990) considers knowledge as a Harrod type, nevertheless the arrangements of the Solow type where knowledge is considered as a substitute of physical capital can be found in other works too, see for instance Youngchan et al. (2010).

In this paper, the Hicks type of technological progress is chosen for the incorporation of knowledge. As Gillingham, Newell and Pizer (2008) point out, "a Hicks-neutral knowledge stock is a common choice for numerical models that include an economywide production function", which is supported for instance by Zürn et al. (2007) or Wang, Wang and Chen (2009) who adopt the same approach. By incorporating knowledge following the Hicks-neutral approach, it is assumed that with an increasing stock of knowledge, the productivity of all other production factors increases, meaning that with more knowledge, there is less labour and capital required. Even though there is no sufficient empirical evidence that could support the choice of this arrangement, this seems to be the most plausible option with respect to the neutrality of knowledge in this type of technological progress and with respect to its common adoption by other authors.

The nested production structure used in the CGE model is provided in Scheme 1. On the higher level of the nest, value added is a combination of knowledge and a capital-labour bundle using the CES I production function. Due to a lack of empirical evidence, the elasticity of substitution between knowledge and capital-labour was chosen $\sigma_{\mathrm{H}}=2.0$, which is close to Wang Wang and Chen (2009) who apply $\sigma_{\mathrm{H}}=2.5$. On the lower nest, split between capital and labour is determined by the demand equations derived from the CES II production function. The substitution elasticities between capital and labour were taken over from the GTAP estimates (Dinamaran, 2006).

Scheme 1

Nested Production Structure Used in the CGE Model

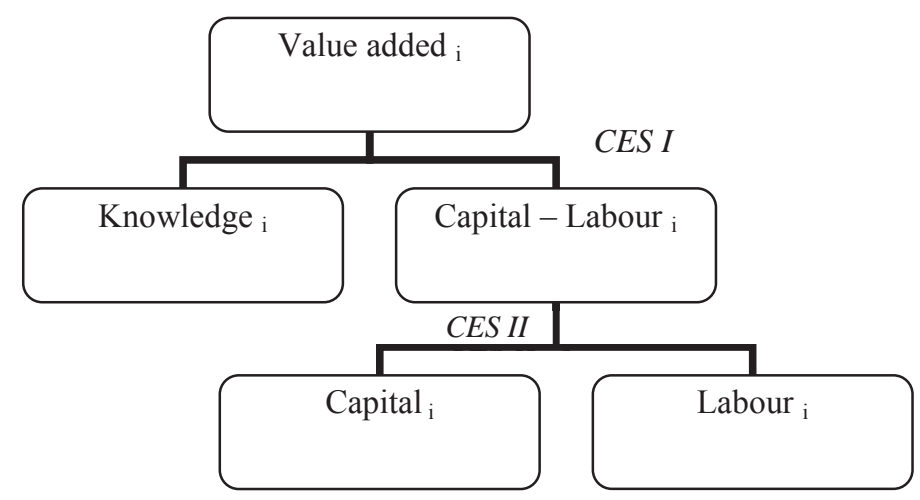

Instead of modelling $R \& D$ within a uniform representative production sector, it is assumed that all production sectors carry out a complementary research activity, which is further distinguished between private and public R\&D. In this way, the R\&D commodity has the role of a by-product, respecting the cost structure of each industry. 
As for the private commodity, R\&D production can be directly determined from the surveys. In the case of a public commodity, it is not directly attributable to production sector, but it can be derived based on the type of institution where the research is carried out. In this work it is assumed that the research carried out for instance under the Ministry of Agriculture, directly stimulates knowledge in agriculture, analogically for other branch research. In the case of research performed by the Czech Academy of Sciences, knowledge is attributed directly to the sector of R\&D. Figure 3 shows the participation of each sector in the production of both public and private $R \& D$ commodities. It can be noted that there are four production sectors that are important in producing the public R\&D commodity, which are: the R\&D sector itself; education, health care and other services that involve activities of public administration, museums and libraries. The majority of research is, however, performed by the private sector $(60 \%)$, predominantly by the car and machinery industry. From the tertiary sector, ICT, banking and commerce are notably active in private research.

Figure 3

Production of R\&D Commodities per Sector (CZK m)

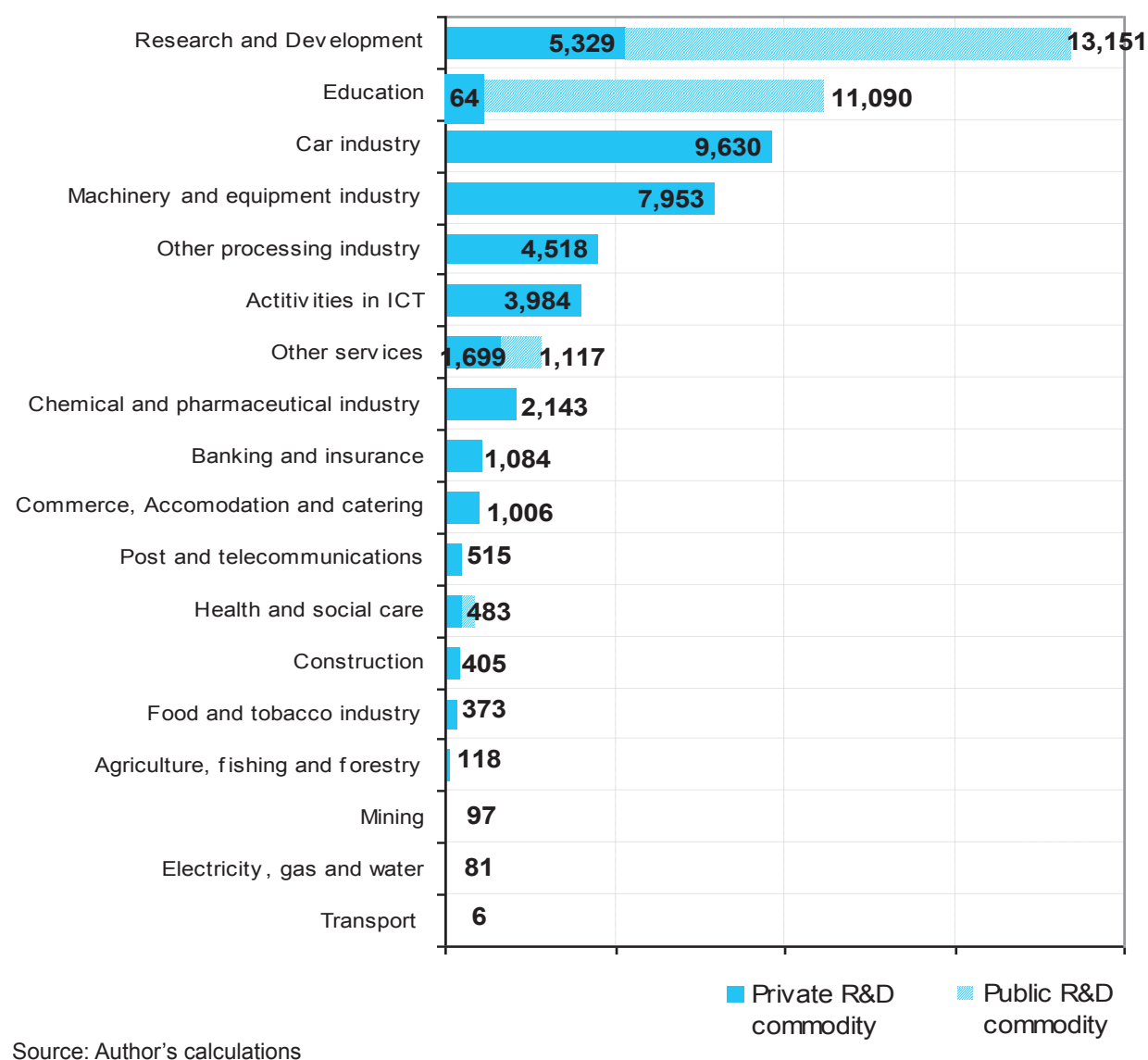


Further modification to the original model was carried out in the investment function. Total investment resources (INVRES), which are determined by total savings and depreciation are distributed between physical investments (INVT) and R\&D investments (INVTRD) on the basis of the Cobb-Douglas investment function, which maximizes a bank's investment utility subject to available investment resources ${ }^{5}$. Derived investment demand functions are displayed in Equation 2 and 3. The choice between investing in R\&D or capital goods is determined by the total investment resources and corresponding prices. PINVT and PINVTRD represent weighted average prices of both types of investments, calculated from the composite commodity prices. Parameters $\alpha_{\text {INVT }}$ and $\alpha_{\text {INVTRD }}$ are calibrated from the equation and represent a share of the respective investment type in total investment resources. In the benchmark period (2008) the parameters are $\alpha_{\text {INVT }}=0.93 \alpha_{\text {INVTRD }}=0.07$, showing a negligible share of R\&D investments in total investment resources. In the following step, the demand for individual investment goods is determined on the basis of fixed coefficients, calibrated from the SAM.

$$
\begin{aligned}
& I N V T=\frac{\alpha_{I N V T} \cdot I N V R E S}{P I N V T} \\
& I N V T R D=\frac{\alpha_{I N V T R D} \cdot I N V R E S}{P I N V T R D}
\end{aligned}
$$

The allocation of investments into the production sectors is crucial for capturing the R\&D effects in future periods. The CGE model follows a recursive form of dynamization, which is fully described in Krrístková (2010b). The investment allocation function of both physical and R\&D investment is modelled following the Tobin's Q specification.

The modified version of the CGE model contains two dynamic equations, which provide a link between the amount of capital and knowledge stock in the current and following periods:

$$
\begin{aligned}
& K S_{i, t+1}=\left(1-\operatorname{sdep}_{i}\right) \cdot K S_{i, t}+I S_{i, t}, \\
& H S_{i, t+1}=\left(1-\operatorname{sdep} H_{i}\right) \cdot H S_{i, t}+I S R D_{i, t}
\end{aligned}
$$

Equation 4 indicates that the amount of capital stock in the current period is determined by the depreciated amount of capital stock in the previous period, raised by the physical investments. Analogically, the stock of knowledge in the current period is determined by net R\&D investments carried out in the previous period (Equation 5).

$5 \quad$ Note: Instead of the Cobb-Douglas investment function, the author also considered the CES investment function, which yielded only negligible impact on the results. 


\subsection{Scenario definition}

The modifications introduced into the CGE model now make it possible to properly address the impact of R\&D investment on the Czech economy. More specifically, the following research questions will be analysed:

1. What is the impact of the knowledge stock accumulation on the predicted economic growth in the Czech Republic?

2. What is the efficiency of R\&D investments compared to physical investments?

3. What would be the impact of a potential increase of EU policy-driven R\&D investment on the macroeconomic behaviour and structural changes to the Czech economy?

In order to respond to the first research question, the CGE model was used in two different settings. In the first setting that represents Model without knowledge, the economy grows only on the basis of physical stock accumulation, which means that the dynamic knowledge stock equation (10) is excluded from the model. The results of this model represent a provisional baseline, against which the economic growth derived from the Model with knowledge that incorporates the dynamic knowledge stock equation (10) is compared. The second and the third research questions are analysed only within the Model with knowledge. Concerning the efficiency of R\&D investments, the impact of different investment mixes on GDP is analysed. The third research question investigates the impact of R\&D stimulus on the economy, induced by EU-led policy aimed at supporting expenditure on research and development.

\section{Simulation Results}

\subsection{Overview of total gross expenditure on research and development}

An overview of total R\&D expenditure and structure according to the performing sector is provided in Figure 4. It can be noted that between 2000-2009, total gross expenditures (GERD) increased two-fold. Also, the share of R\&D expenditure in GDP grew from $1.2 \%$ to $1.5 \%$. Whereas the private GERD still represents the biggest part of total R\&D spending, even more dynamic GERD development is observed in the case of university research, which can be attributed with the EU accession. 
Figure 4

Overview of Gross R\&D Expenditure per Performing Sector (CZK m)

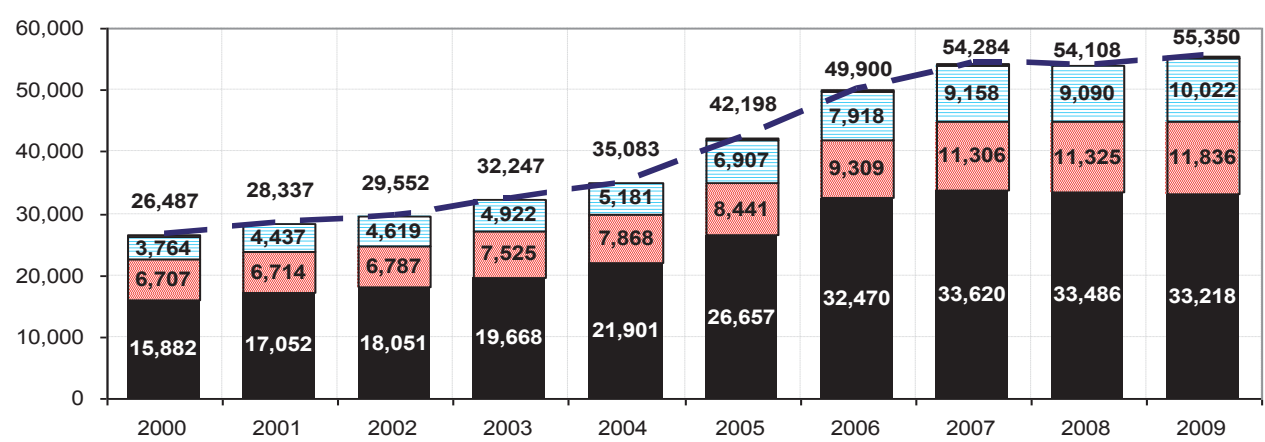

Data source: CZSO, Frascati Manual

Figure 5 provides a comparison of GERD share in GDP among selected European countries and OECD members. From this group, Finland has the highest share of R\&D expenditure (3.7\%), which is double that of the Czech Republic (1.47\%). Other EU-15 countries report higher shares as well, such as Germany (2.6\%) and France $(2.15 \%)$, shares of Italy and the Great Britain are lower (1.19\% and $1.7 \%$ respectively). The average EU-27 level is still above the Czech Republic (1.81\%) and even larger is the gap with the average OECD standard (2.3\%). However, compared to other newly accessed EU states such as Hungary and Poland, the GERD expenditures in the Czech Republic are relatively high.

Figure 5

Share of GERD in GDP in Selected Countries

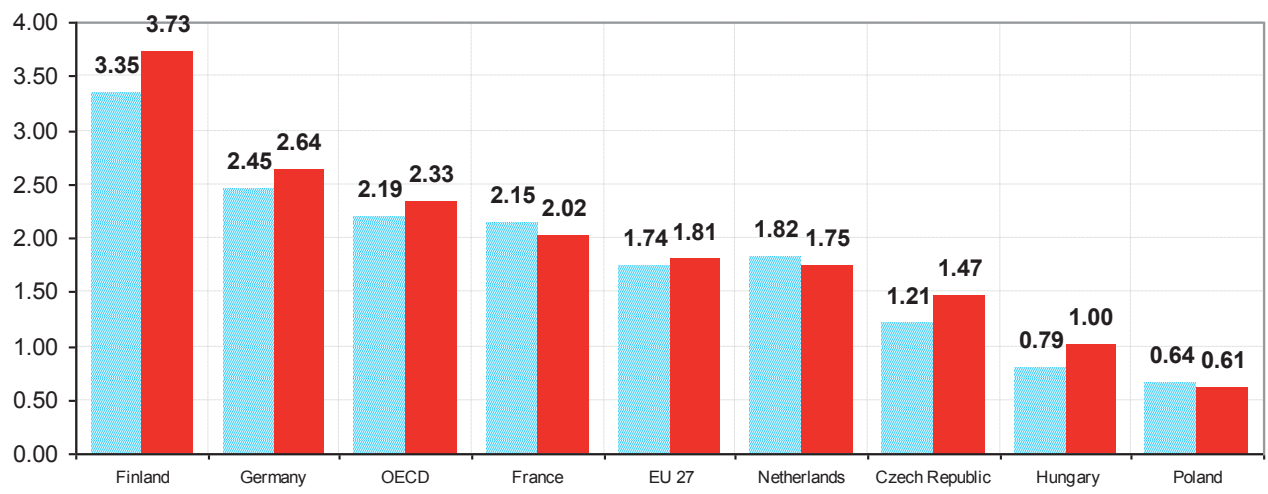

Data source: CZSO, Frascati Manual 


\subsection{Impact of R\&D capitalization on the dynamics of economic growth}

In this chapter, the effect of knowledge accumulation driven by R\&D investment on the dynamics of economic growth is investigated. For this purpose, two models - one which includes knowledge and one in which knowledge is omitted - are analysed and their macroeconomic behaviour compared.

According to the endogenous growth theory, it is expected that the inclusion of knowledge will have a positive impact on economic growth. This hypothesis is confirmed by observing the development of nominal GDP values in the two respective models (Figure 6). However, due to the inclusion of the R\&D investment in GDP in the initial period, the benchmark equilibrium states in the two models differ slightly. Therefore, it is not possible to fully compare the two GDP indicators in their nominal values, rather to assess their relative performance in the form of growth rates.

Figure 6

Comparison of Nominal GDP (CZK bn c.p.) in Models with and without Knowledge

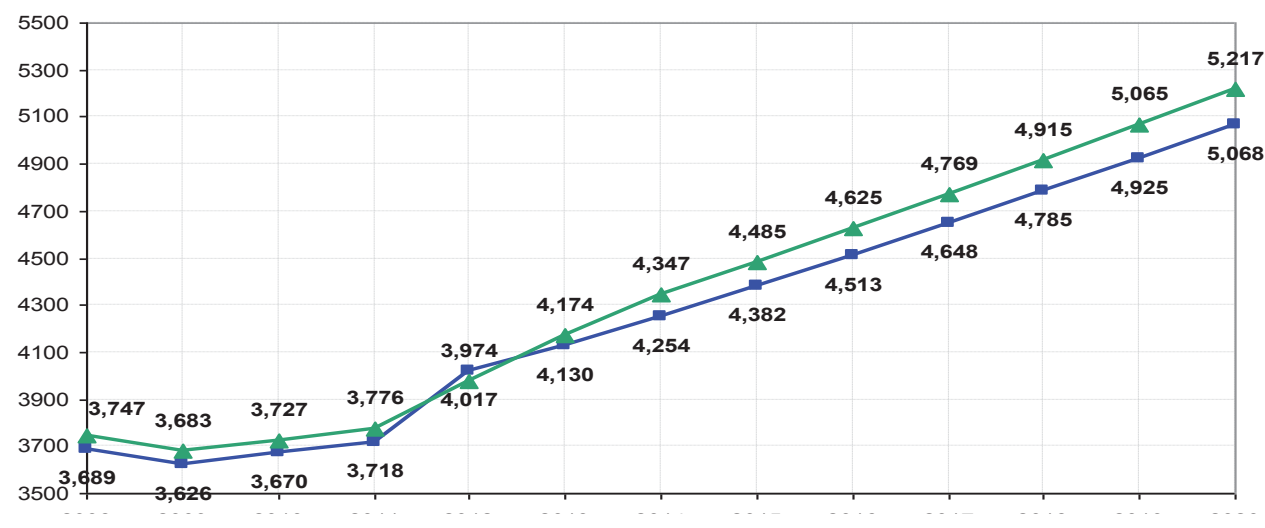

Source: Author's calculations

GDP growth rates of both models are presented in Table 2. The development of GDP growth is affected by the financial and economic crisis; in 2009 GDP declined by 4\%, followed by slow growth in 2010 and 2011. From 2013, the model without knowledge reports lower GDP growth rates.

Table 2

GDP Growth Rates of Both Models

\begin{tabular}{|l|c|c|c|c|c|c|c|c|c|c|c|c|c|}
\hline $\mathbf{t}$ & $\mathbf{2 0 0 9}$ & $\mathbf{2 0 1 0}$ & $\mathbf{2 0 1 1}$ & $\mathbf{2 0 1 2}$ & $\mathbf{2 0 1 3}$ & $\mathbf{2 0 1 4}$ & $\mathbf{2 0 1 5}$ & $\mathbf{2 0 1 6}$ & $\mathbf{2 0 1 7}$ & $\mathbf{2 0 1 8}$ & $\mathbf{2 0 1 9}$ & $\mathbf{2 0 2 0}$ & Average \\
\hline $\begin{array}{l}\text { Model w/o } \\
\text { knowledge }\end{array}$ & $-4.20 \%$ & $2.30 \%$ & $1.90 \%$ & $5.27 \%$ & $1.24 \%$ & $1.19 \%$ & $1.20 \%$ & $1.19 \%$ & $1.17 \%$ & $1.15 \%$ & $1.12 \%$ & $1.09 \%$ & $1.71 \%$ \\
\hline $\begin{array}{l}\text { Model with } \\
\text { knowledge }\end{array}$ & $-4.20 \%$ & $2.30 \%$ & $1.90 \%$ & $2.54 \%$ & $3.43 \%$ & $2.31 \%$ & $1.37 \%$ & $1.31 \%$ & $1.29 \%$ & $1.26 \%$ & $1.23 \%$ & $1.19 \%$ & $1.83 \%$ \\
\hline
\end{tabular}

Source: Author's calculations 
Even though Table 2 confirms the initial expectation that a knowledge-based CGE model provides higher GDP growth rates, the impact is surprisingly very small. It can be concluded that capitalization of knowledge can trigger average growth rates only by 0.12 percentage points. On the other hand, this finding is plausible if we take into account that in the benchmark period, the share of knowledge in the total gross value added is estimated at $5 \%$, with considerable differences between sectors; for instance the car industry and the R\&D sector employ $10 \%$ of knowledge in total value added, in most other sectors, knowledge accounts for less than $1 \%$ of GVA.

The impact of different dynamisation forms compared in this paper is also analysed with respect to the structure of the economy. In the developed economies, the share of primary sector (agriculture and mining) and secondary sector (processing industry and construction) is less significant compared to the tertiary sector represented by services, such as banking and commerce. In the most developed economies, the accent is also put on the quaternary sector, which represents the knowledge economy. This sector includes education, health care, research and development and governmental services.

Figure 7 shows how this structure develops over time under the two dynamic models. In the case of the model without knowledge, the share of quaternary services slightly declines in favour of the secondary sector. This is attributed to a high representation of industrial goods in total investments. In particular, the construction sector produces $50 \%$ of investment commodities, $23 \%$ is produced in the machinery and equipment sector. On the other hand, in the model with knowledge, the tertiary and quaternary services increase their share in value added at the expense of the secondary sector. This leads to the conclusion that the CGE models which omit knowledge in their dynamisation slightly overestimate the growth of the secondary sector over time, at the expense of services.

\section{Figure 7}

Structural Changes in the Economy under Both Types of Models

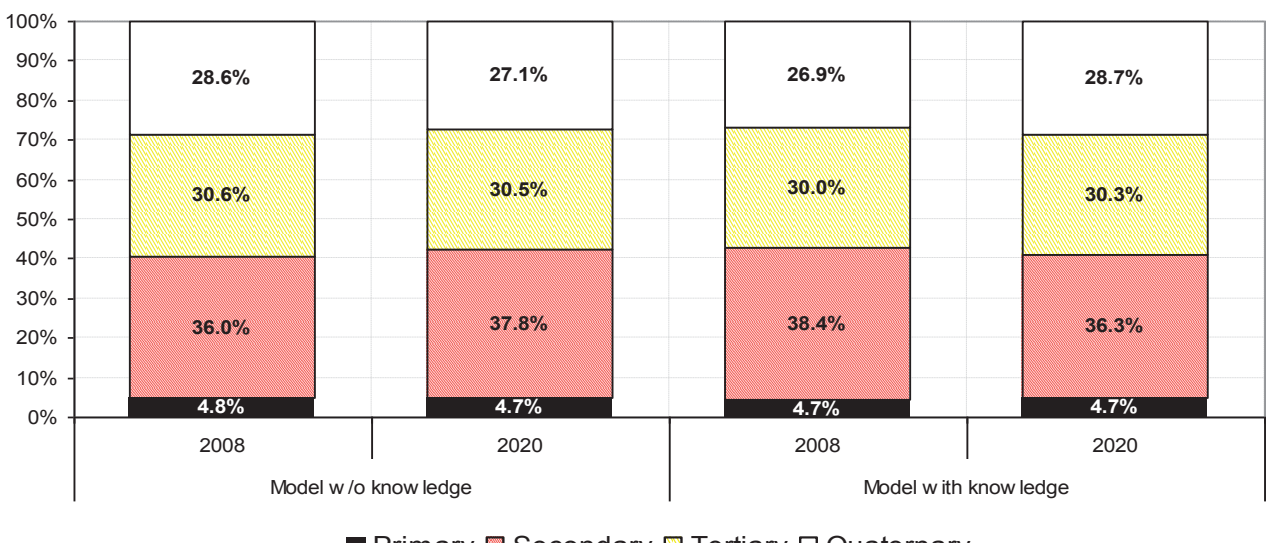

- Primary $\square$ Secondary $\square$ Tertiary $\square$ Quaternary 


\subsection{The efficiency of R\&D investments vs. physical investments}

The last finding on the positive effect of knowledge accumulation on the structure of the economy leads to an investigation of another issue, that of the efficiency of R\&D investment. Would it be more desirable to invest in R\&D commodities such as innovation, patents or research papers instead of investing in capital goods such as construction or machinery? The following simulation examines this issue by varying the Cobb-Douglas parameter that indicates the share of R\&D investment in total investment resources. It should be pointed out, that in this exercise the increase of R\&D investment is at the expense of physical investment in order to maintain equilibrium between total investment resources and their use. The results of the simulation are provided in Figure 8.

The benchmark GDP level reaches CZK 3,747 billion, corresponding to Alpha IRD equal to 0.07 . Figure 8 clearly demonstrates that a small increase in parameter alpha IRD and thus in the share of R\&D investment can have a positive effect on GDP. GDP continues to grow until it reaches a peak after which a too excessive level of R\&D investment can be detrimental to the economy. It can be noted that the peak is exactly at the point that corresponds to the OECD level of R\&D investment, measured as a percentage of GDP. On the other hand, if the parameter Alpha IRD is reduced, a slight decline in GDP can be expected.

\section{Figure 8}

Static Effects of Different R\&D Investment Shares on GDP (CZK bn c.p.)

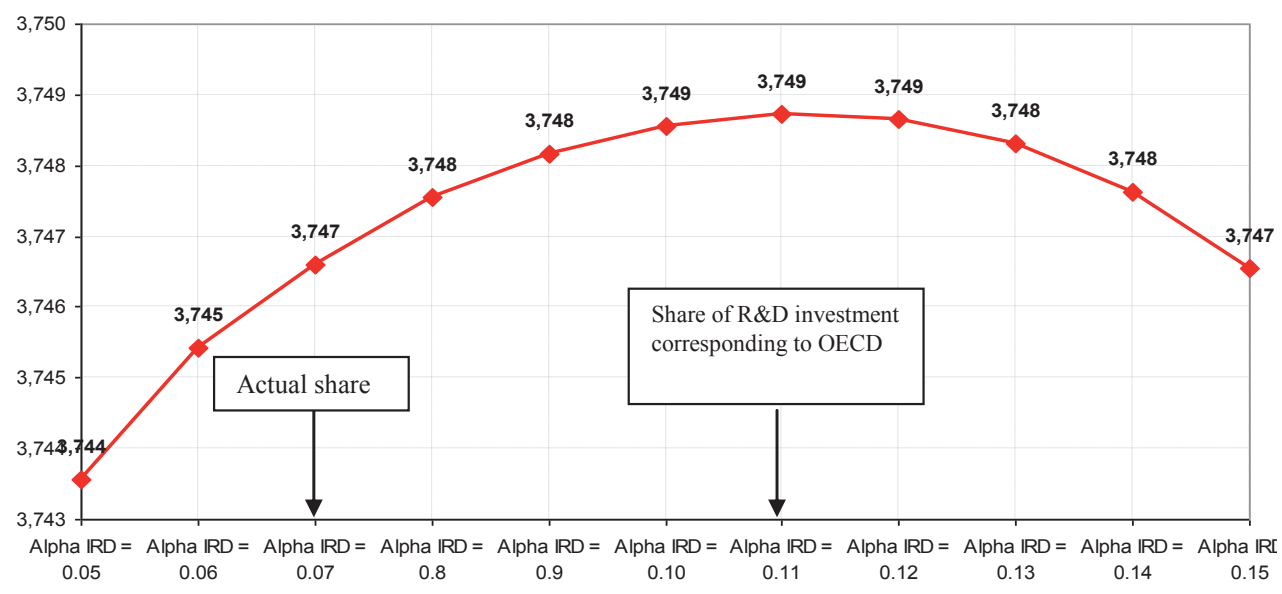

Source: Author's calculations

Nevertheless, it is maybe more useful to analyse the efficiency of R\&D investment in the longer run, and see if the static results also hold in the dynamic model. According to Figure 9, any increase of R\&D investment share in the long run causes a decline in GDP. Therefore, there is a certain contradiction between the results of the static 
and dynamic model. Whereas in the static model, a certain increase of R\&D share can be positive for the economy, in the long run, any positive deviation from this share can cause a GDP decline. The extreme case of the AlphaIRD parameter reaching 0.15 shows that GDP in 2020 would be $2.6 \%$ points below baseline. Another extreme case is considered with Alpha IRD $=0.04$ in which the share of $R \& D$ investment is reduced ${ }^{6}$. In this case, GDP can reach $0.5 \%$ points more than baseline.

Figure 9

Dynamic Effects of Different R\&D Investment Shares on GDP Percentage deviation from baseline - AlphalRD $=0.07$

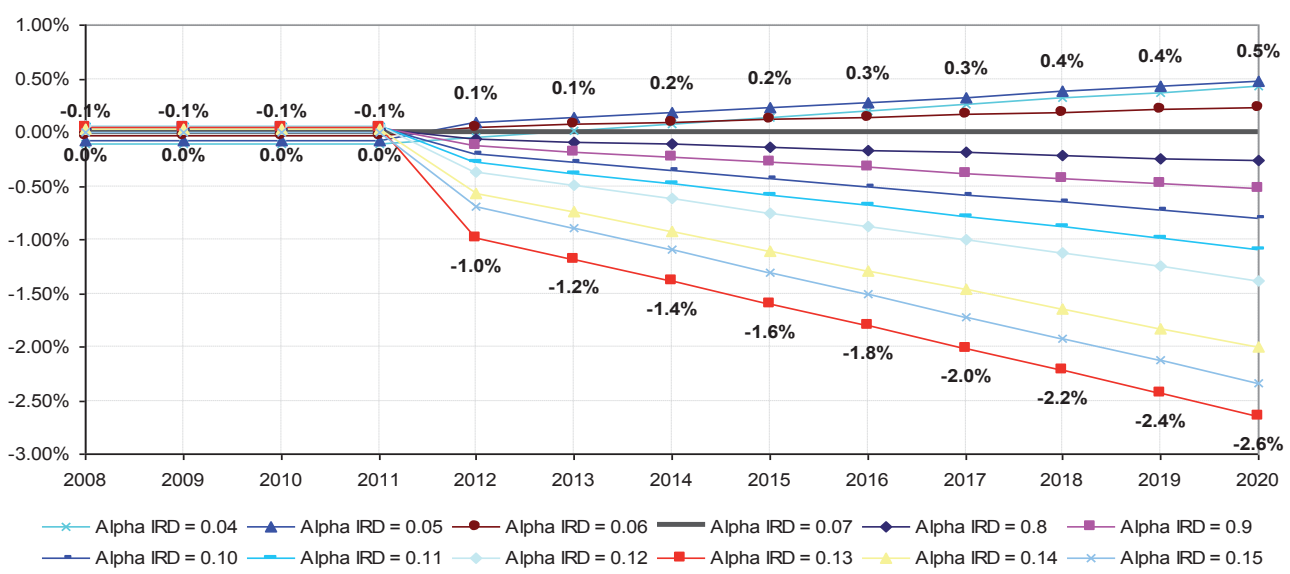

Source: Author's calculations

This contradictory finding requires analysing the cause of the GDP decline under changing proportions of investments in favour of R\&D. Particularly, the structure of the economy is examined under the two extreme cases, considering R\&D investment shares of $15 \%$ and $4 \%$. With the use of the absolute deviations, value added per sector in the final year of the analysed period is compared. The results reported in Figure 10 leads to findings that there are substantial structural differences in the economy under both extreme conditions. Considering R\&D investment share at a $15 \%$ level, an excessive increase of R\&D sector ( +44 bn) and car industry $(+19$ bn) is reported. Except for the machinery and chemical and pharmaceutical sector which also benefit from higher R\&D investment shares, all other sectors of the economy have a smaller size compared to the model with lower R\&D investments. The strongest decline of value added can be observed in the case of the construction sector ( $-40 \mathrm{bn}$.) and the sector, other services (-30 bn.). Based on these findings it can be concluded that the stimulation of R\&D investments at the expense of the physical investments produces suboptimal allocation of resources. Apparently, the major sectors producing R\&D investment commodity such as the R\&D sector or the car industry cannot stimulate

6 The model cannot be run with simulations lower than alphaIRD $=0.04$. 
economic growth at the same extent as the other sectors of the economy, namely construction, other services or processing industries. One of the reasons is a high specialization of particular sectors on the production of capital goods for which even a small decline in investment demand may negatively affect their production results. Such a sector is, for instance, construction where in 2008 more than $50 \%$ of production was designated for investment goods.

Figure 10

Absolute Difference of Value Added in 2020 (CZK bn s.p.2008) Alpha IRD=0.15 vs.

Alpha IRD $=0.04$

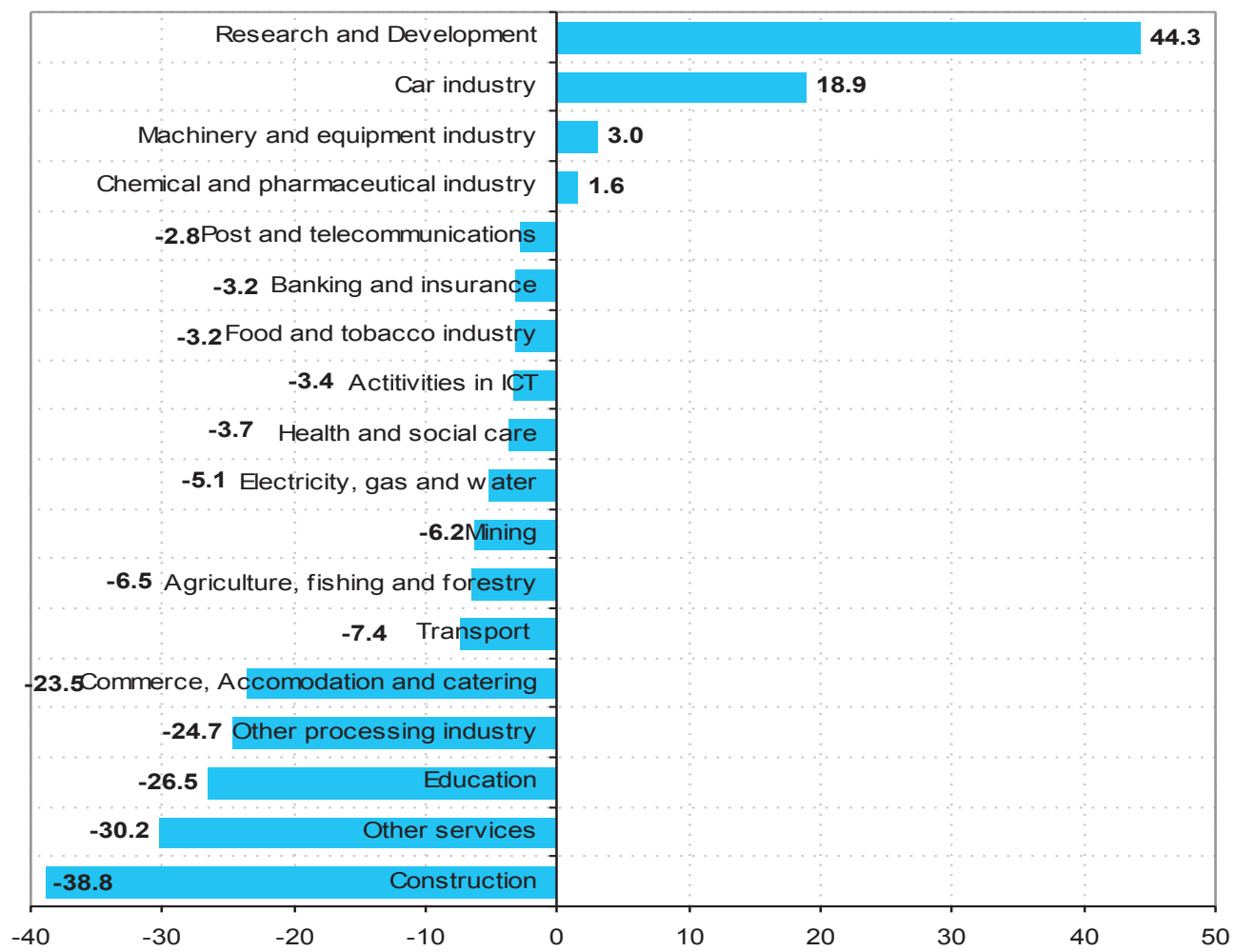

Source: Author's calculations

\subsection{Impact of R\&D stimulus on the economy}

As the results of the previous chapter show, it is not possible to expect a positive impact of R\&D investment if these are stimulated at the expense of physical investment. Even though in the short term this might be beneficial, in the long term this trade off can decelerate economic growth. 
Therefore, in the last simulation, an exogenous R\&D stimulus that directly increases the investment resources for R\&D goods is incorporated in the model and its impact on economic growth is calculated. In this exercise, it is assumed that in compliance with the EU Strategy 2020, there is an inflow of EU support to the Czech economy, which is directed to investment resources in $\mathrm{R} \& \mathrm{D}$. This simulation is produced in the benchmark period, and its short and long-term impacts are analysed. In the simulation, the R\&D investment resources increase by CZK 25 billion, which raises the total R\&D investment in the Czech Republic to the OECD level, measured in terms of GDP share. Furthermore, it is approximately the same amount as the total subsidies distributed to Czech farmers from the EU Common Agricultural Policy budget. This gives an impression of the scale of the simulation, which is comparable to a size devoted to the support of a specific branch of the national economy.

Figure 11 shows changes in GDP produced by the simulation. It can be noted that increasing foreign investment resources for R\&D can lead to a higher GDP level at the end of the analysed period $(1 \% \text { increase })^{7}$.

Figure 11

Impact of R\&D Stimulus on GDP (CZK bn c.p. 2008)

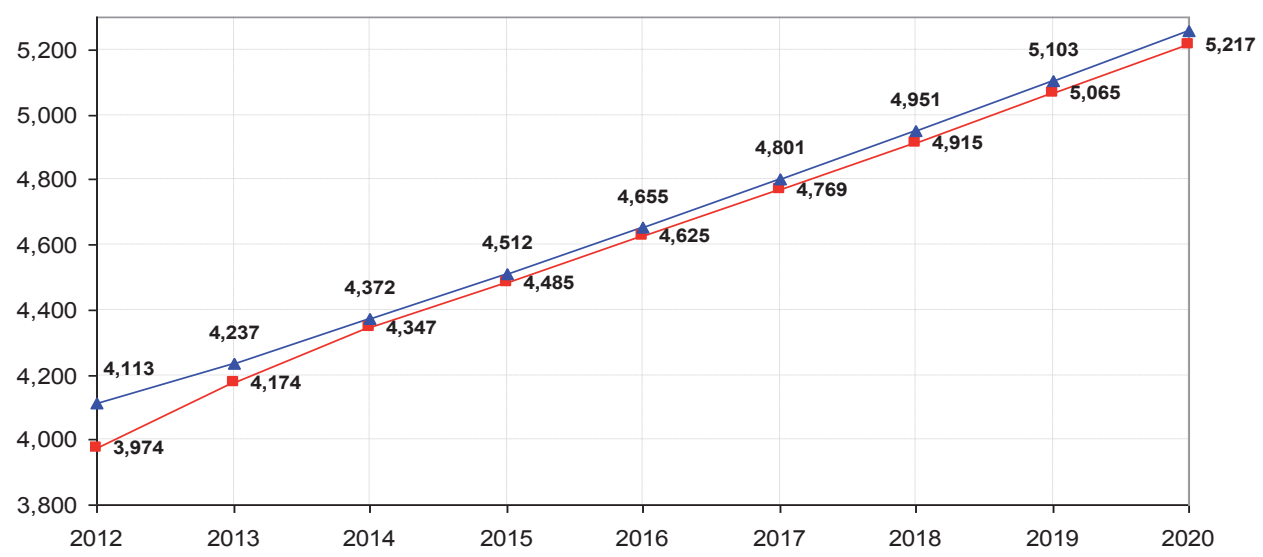

Source: Author's calculations

Despite such a small impact on growth, for many sectors, the increase in $R \& D$ investment resources can be important. Figure 12 reports sectors with more than one percentage increase of value added compared to baseline. Besides the R\&D sector (+ $13 \%)$, gross value added is stimulated in the construction sector $(+2 \%)$, car industry $(+2 \%)$, ICT $(+1.7 \%)$ and chemical and pharmaceutical industry $(+1.1 \%)$. These are mainly the sectors with high knowledge accumulation, except for the construction sector that benefits from the economic investment boom. In most other sectors, the impact is also positive, though smaller than $1 \%$.

7 Simulations concerning a parallel removal of subsidies in agriculture corresponding to the value of additional investment $R \& D$ resources showed no impact on economic growth. 
Figure 12

Impact of R\&D Stimulus on Gross Value Added (c.p. 2008) Relative Differences in \%.

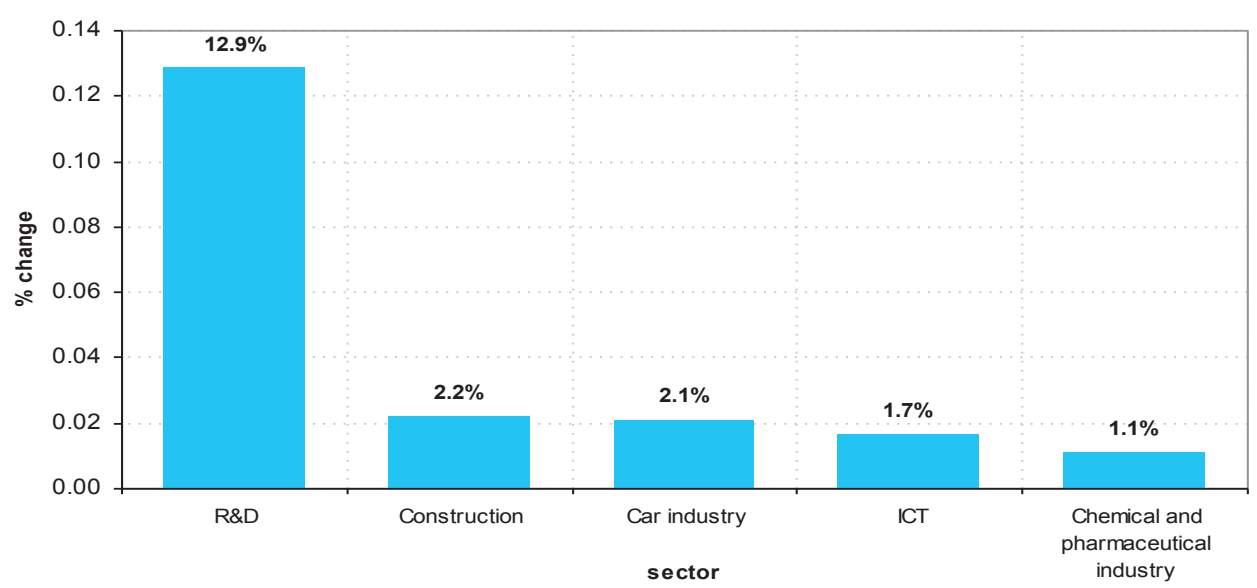

Source: Author's calculations

Changes are also produced concerning the structure of GDP expenditures. Table 3 reports the aggregate consumption, investment, exports and imports in the baseline and R\&D stimulus scenario. Values are reported in 2020 both in current prices and also in percentage and absolute differences. The strongest increase is observed in case of investment that is directly linked to the performed simulation. However, it can also be observed that the R\&D stimulus produces a notable growth of imports, which acts negatively on GDP. When analysing the import structure it is discovered, that the increase of imports is driven predominantly by five investment commodities: machinery and equipment, automobiles and other industrial goods, and to a lesser extent the R\&D private commodity and pharmaceuticals. This finding is closely linked to a high share of imported commodities in total investment goods. Thus, any increase in investment demand is going to require more imported commodities and will offset the positive effect on GDP.

Regarding aggregate consumption and exports, the changes produced by the $R \& D$ stimulus are comparable and both are positive.

Table 3

Impact of R\&D Stimulus on GDP Components (2020)

\begin{tabular}{|l|c|c|c|c|}
\hline GDP components 2020 & $\begin{array}{c}\text { Baseline R\&D } \\
\text { CZK bn. (c.p.) }\end{array}$ & $\begin{array}{c}\text { R\&D shock } \\
\text { CZK bn. (c.p.) }\end{array}$ & $\begin{array}{c}\text { \% Difference } \\
\text { vs. Baseline }\end{array}$ & $\begin{array}{c}\text { Absolute Diff. vs. } \\
\text { Baseline }\end{array}$ \\
\hline CONSUMPTION & 2,486 & 2,491 & $0.2 \%$ & 5 \\
\hline GOVCONS & 895 & 900 & $0.6 \%$ & 5 \\
\hline INVESTMENT & 1,561 & 1,615 & $3.4 \%$ & 54 \\
\hline EXPORTS & 3,927 & 3,932 & $0.1 \%$ & 5 \\
\hline IMPORTS & 3,652 & 3,680 & $0.8 \%$ & 28 \\
\hline Total GDP & 5,217 & 5,258 & $0,8 \%$ & 41 \\
\hline
\end{tabular}

Source: Author's calculations 
Finally, the impact on the situation of households is investigated (Table 4). It can be noted that the stimulation of R\&D investment can lead to a positive effect on the labour market - the unemployment rate decreased by $1.2 \%$. Furthermore, the welfare of households measured by equivalent variation is increased by $1.5 \%$ compared to baseline.

Table 4

Impact of R\&D Stimulus on Households in 2020 (CZK bn)

\begin{tabular}{|l|c|c|c|}
\hline & Baseline R\&D & R\&D shock & \% Difference vs. Baseline \\
\hline Unemployment (ths of workers) & 273 & 270 & $-1.2 \%$ \\
\hline Household Income (CZK bn) & 3774 & 3782 & $0.2 \%$ \\
\hline Equivalent Variation (CZK bn) & 712 & 723 & $1.5 \%$ \\
\hline
\end{tabular}

Source: Author's calculations

\section{Discussion and Conclusions}

This paper investigated the effect of $R \& D$ investment on economic growth from two perspectives, the methodological perspective and the economic perspective. From the methodological perspective, the aim was to assess what would be the impact on results of a CGE model with R\&D investment and knowledge accumulation, compared to results of a CGE model without knowledge. From the economic perspective, the aim was to analyse the role that R\&D plays in the Czech economy and to derive corresponding conclusions. In order to gain satisfactory insights, R\&D investment was analysed with respect to its impact on GDP and other macroeconomic variables, furthermore with respect to their efficiency compared to physical investment. Finally, the $R \& D$ effects were examined in a scenario which leads to an increase in $R \& D$ investment to reach OECD levels.

With respect to the role of knowledge in the dynamisation of the CGE model, the paper showed that there are only minor effects on GDP compared to results from the model that excludes knowledge. This finding is of course influenced by the length of the analysed period. In this paper, the model provides solutions until 2020, if this period is extended the impacts could be more pronounced, as for instance in Zürn et al. (2007) who derive $1.2 \%$ GDP effects in 2020 and $1.8 \%$ in 2030 . Nevertheless, the importance of knowledge inclusion does not necessarily lay in the dynamics of economic growth but rather in its effect on the structure of the economy. The analysis showed that the CGE model without knowledge overestimated the secondary sector in the longer run, at the expense of services.

Regarding the efficiency of R\&D investment, it was concluded that the positive effects gained from increased investment on account of capital goods were only temporary. In the longer term, the CGE model shows that R\&D investment is less efficient in producing value added compared to investment in capital goods. The inefficiency 
of R\&D investments in the longer term is partially determined by the flexibility of substitution between physical and R\&D investments in the CGE model, which can be disputed in the reality.

Besides the theoretical assumptions of the CGE model, the results are also influenced by the availability of data. There seems to be a potential in analysing firm-level data and econometrically estimating the effects of R\&D investments on the companies' Total Factor Productivity with the aim to specify the type of technological progress. Furthermore, on the macro-level, the application of the revised standard SNA 2008 with a more accurate measurement of $R \& D$ in the national economy, can further improve the results. In addition, it seems that the model should also incorporate R\&D spill-over effects from abroad, which in the case of the Czech Republic, being a small opened economy with a considerable share of FDI investments, might be very relevant as further analysed in Lejour and Rojas-Romagosa (2008).

The CGE model revealed some interesting insights into the role of R\&D investments in the Czech economy. It was found that if R\&D investment is stimulated as a result of EU efforts for smart and sustainable growth, positive effects on all GDP components could be expected. These positive effects stem from the impact of R\&D investment on increased total factor productivity, which is an important source of economic growth. Furthermore, these positive effects are translated across most industries and services. The negative impact on trade balance as a consequence of increased demand for imported capital goods, is offset by a reduced unemployment rate and higher consumer welfare.

\section{References}

Czech Statistical Office (CZSO) (2011), Research and Development Statistics, 2001-2009. Available at: http://www.czso.cz/csu/redakce.nsf/i/statistika_vyzkumu_a_vyvoje, Updated January 31, 2011.

Daniels, M., Statistics Sweden (2007), "Capitalising R\&D." Yearbook on Productivity, Sweden Statistics, pp. 63-74.

Diao, X., Roe, T., Yeldan, E. (1999), "Strategic Policies and Growth: An Applied Model of R\&D Driven Endogenous Growth". Journal of Development Economics Vol. 60, pp. 343-380.

Dinamaran, B. (2006), "Global Trade, Assistance and Production." The GTAP 6 Data Base, Software documentation. Centre for Global Trade Analysis, Department of Agricultural University, Purdue University, December 2006.

Dybczak, K., Voňka D., Van der Windt, N. (2008), "The Effect of Oil Price Shocks on the Czech Economy." Czech National Bank Working Paper Series 5, Prague, p. 40. ISSN 1803-7070.

Galindo-Rueda, F. (2007), "Developing and R\&D Satellite Account for the UK: A preliminary analysis." Economic \& Labour Market Review, Volume 1, No. 12, pp. 18-29.

Garau, G., Lecca, P. (2008), "Impact Analysis of Regional Knowledge Subsidy: A CGE Approach". Working Papers CRENoS, 11. pp. 36. ISBN 978-88-8464-471-5.

Gillingham, K., Newell, R. G., Pizer, W. A. (2008), "Modelling Endogenous Technological Change for Climate Policy Analysis". Energy Economics, Vol. 30, No. 6, pp. 2734-2753. 
Haan, M. de, Rooijen-Horsten, M. van (2004), "Measuring R\&D Output and Knowledge Capital Formation in Open Economies", Discussion paper 04009, Paper prepared for the 28th General Conference of the International Association for Research in Income and Wealth, Statistics Netherlands. ISSN: 1572-0314.

Hurník, J. (2004), "Fiscal Consolidation in General Equilibrium Framework (The Case of the Czech Republic)." Prague Economic Papers, Vol. 52, No. 2, pp.142-158.

Kejak, M., Seiter, S., Vávra, D. (2004), "Accession Trajectories and Convergence: Endogenous Growth Perspective." Structural Change and Economic Dynamics, Vol. 15, No 1, pp. 13-46.

Kejak, M., Vávra, D. (2002), "Factor Accumulation Story: Any Unfinished Business?" CERGE-EI Working Paper, No. 220, p. 46.

Křístková, Z. (2010a), "Impact of the Common Agricultural Policy Reform on the Czech Economy, a General Equilibrium Approach". Paper presented at the International Conference on Economic Modelling, Ecomod, 2010.

Krístková, Z. (2010b), "Approaches to the Dynamization of the CGE Model Applied to the Czech Republic." Emerging Markets Finance \& Trade, May-June 2010, Vol. 46, Supplement No. 1, pp. 59-82. ISSN 1540-496X/2010.

Lejour, A., Rojas-Romagosa, H. (2008), "International Spillovers of Domestic Reforms: The Joint Application of the Lisbon Strategy in the EU." CPB Netherlands Bureau for Economic Policy Analysis, Discussion Paper No. 105. ISBN 978-90-5833-355-1.

OECD (2003), "Frascati Manual 2002: Proposed Standard Practice for Surveys on Research and Experimental Development." Paris, pp. 256. ISBN: 9789264199040 (PDF).

Pavel, J. (2006), Macroeconomic Models of the Impact of the Environmental Policy Measures on the Macroeconomic Aggregates in the Czech Republic. Institute for Economic and Environmental Policy (IEEP), Czech Republic, p. 186. ISBN 80-86684-40-7.

Ptáčková, Z. (2007), "Research and Development in the System of National Accounts". Statistika, No. 3, pp. 232-248.

Robbins, C. A. (2005), "Linking Frascati-Based R\&D Spending to the System of National Accounts." Paper prepared for the Conference of the Group on Measurement of Non-Financial Assets (Canberra II), March 29-April 1, 2005, Canberra, Australia.

Romer, P. M. (1990), “Endogenous Technological Change." The Journal of Political Economy, Vol. 98, No. 5, pp. 71-102.

Salem, M., Siddiqi, Y. (2006), "A Proposal for Treating Research and Development as Capital Expenditures in the Canadian SNA." Economic Analysis (EA) Research Paper Series, ISSN: 1703-0404, June 2006.

Ščasný, M., Píša, V., Pollott, H. et al. (2009), "Analyzing Macroeconomic Effects of Environmental Taxation in the Czech Republic with the Econometric E3ME Model". Czech Journal of Economics and Finance, Vol. 59, Issue 5, pp. 460-491.

Sixta, J., VItavská, K., Zbranek, J. (2011), "Total Factor Productivity Based on Services of Labour and Capital". Politická ekonomie, 2011, Vol. 59, No. 5, pp. 599-617. ISSN 0032-3233.

Wang, K., Wang, C., Chen, J. (2009), "Analysis of the Economic Impact of Different Chinese Climate Policy Options Based on a CGE Model Incorporating Endogenous Technological Change." Energy Policy, Vol. 37, pp. 2930-2940.

Yungchang J., B., Yih-Chyi Ch., Wei-Wen L. Chung-Min Y. (2010), "A Dynamic General Equilibrium Model for Public R\&D Investment in Taiwan.” Economic Modelling, Vol. 27, No. 1, pp.171-183.

Zbranek, J., Fischer, J. (2010), "Impact of Capitalization of R\&D Expenditures on Macroeconomic Aggregates". Statistika, Vol. 90, No. 1, pp. 28-46. ISSN 0322-788X.

Zürn, M., Küster, R., Ellersdorfer, I., et al. (2007), "R\&D Investment and Knowledge Input in a Technology Oriented CGE Model". Paper presented at EcoMod Conference on Energy and Environmental Modelling, Moscow, 2007. 